\title{
DEVELOPMENT OF PAPERLESS FOREIGN TRADE PERFORMANCE MEASUREMENT SCALE: THE MULTITRAIT-MULTIMETHOD MODEL PROPOSAL
}

\author{
MUSTAFA EMRE CIVELEK ${ }^{6}$, NAGEHAN UCA ${ }^{7}$
}

\begin{abstract}
The purpose of this paper is to propose a scale development method to measure the performance of foreign trade companies in paperless trade operations. First, a qualitative interview method was used to determine the dimensions of the scale. As a result of this study, it was found that paperless trade performance has primary and secondary dimensions. This two level dimensionality lead to multitrait multimethod model (MTMM) in order to determine the construct validity. This paper consists of scale proposal to measure paperless trade performance under the primary dimension (payment, customs, insurance, transport, archiving) from the secondary dimensions perspective (speed, errors, costs, security, predictability, tracking \& tracing, reporting). Findings show that a complex nested model is needed to verify the validity of the scale. The theoretical contribution of this research is the development of a method for a scale in paperless trade. The managerial contribution of this research is to provide an instrument for assessing the paperless trade performance of foreign trade companies.
\end{abstract}

Keywords: Foreign Trade, Multitrait-Multimethod Model, Paperless Trade

JEL Codes: M10, F19

\footnotetext{
${ }^{6}$ Assist. Prof., Istanbul Commerce University, Faculty of Business, ecivelek@ticaret.edu.tr

${ }^{7}$ Assist. Prof., Istanbul Commerce University, Faculty of Business, nuca@ticaret.edu.tr
} 


\title{
KAĞITSIZ DIŞ TICARET PERFORMANS ÖLÇEĞi GELIŞTIRIILMESI: ÇOKLU ÖZELLIK ÇOKLU YÖNTEM MODELI ÖNERISI
}

\begin{abstract}
ÖZET
$\mathrm{Bu}$ çalışmanın amacı, dış ticaret şirketlerinin kâğıtsız ticaret operasyonlarındaki performanslarını ölçmek için ölçek geliştirme yöntemi önermektir. ilk olarak ölçeğin boyutlarının belirlenmesi için nitel mülakat yöntemi kullanılmıştır. Yapılan bu çalışmanın sonucunda kâğıtsız ticaret performansının birincil ve ikincil boyutlara sahip olduğu tespit edilmiştir. Bu iki seviyeli boyutlulukta yapı geçerliliğinin doğrulanabilmesi çoklu özellik çoklu yöntem modeli ile sağlanabilmektedir. Bu çalışma birincil boyutlar altında (ödeme, gümrük, sigorta, nakliye, arşivleme) ikincil boyutlar (hız, hata, maliyet, güvenlik, öngörülebilirlik, takip ve izleme, raporlama) perspektifinden kâğıtsız ticaret performansını ölçen bir ölçek önerisini içermektedir. Bulgular, ölçeğin geçerliğinin doğrulanması için karmaşık iç içe geçmiş bir modele gereksinim duyulduğunu göstermektedir. Bu araştırmanın teorik katkısı kağıtsız ticaret alanında kullanılacak bir ölçek için yöntem geliştirilmiş olmasıdır. Bu araştırmanın yönetsel katkısı ise dış ticaret şirketlerinin kağıtsız ticaret performanslarını değerlendirmek için bir araç sağlamasıdır. Bu çalışmanın bu alanda yapılacak olan gelecek araştırmalara ışık tutması beklenmektedir.
\end{abstract}

Anahtar Kelimeler: Dış Ticaret, Çoklu Özellik-Çoklu Yöntem Modeli, Kağıtsıı Ticaret

JEL Kodları: M10, F19 


\section{Introduction}

Technological developments in recent years have caused paper based documentation will be completely deserted in all business processes, but since foreign trade consists complicated business processes, the paper-based processes are still commonly used in transactions. Electronic documents are the electronic records. And this record should bear electronic signature in order to gain legal validity. Legal validity of an electronic document stems from certificate authorities. They are integrated components in this record such as statements, writings, figures and pictures. The most important barrier to the development of electronic trade is the standardization problem of electronic documents (Civelek, Çemberci, Uca, Çelebi, \& Özalp, 2017). The trials in the Asia region enhance harmonization of procedures and systems that are necessary for integrated paperless trade processes (Laryea, 2005). Psychological and management issues are important because some of the problems in putting electronic document systems into use are not only technical (Björk, 2006). Paper documents are still used in some offices, and employees still have some problems in using electronic documents. These problems have continued in spite of the development of software and hardware technology making electronic documents available. The difference between paper and electronic documents cause problems. Also, the difference among electronic documents causes problems. Therefore there is a need for more integrated electronic document processing system (Jervis \& Masoodian, 2014).

For developing the international trade process, in some countries, electronic document projects were implemented. In addition, to provide a single window for foreign trade there are some attempts. However, the evaluation of the use of electronic documents is still slow. The development of paperless trade performance has some positive or negative results. Positive results were shown at the initial stage as decreases costs of the operational transactions and increases productivity. However, some opposite results have suggested in the current literature. Negative results were observed in the later stages at the company level. This shows that there is a need for a measure to observe the performance increase in the foreign trade companies. The use of electronic documents is not continuously increase if the benefits do not match with expected performance. Consequently, benefit of electronic documents is not clear to increase the firm performance (Kim \& Lee, 2016). For increasing performance, an important opportunity is seen in the digitalization of the paper documents (Leyer \& Hollmann, 2014). Increase in the performance is directly related to the attitudes of the users and for changing user attitudes towards electronic documents, there is a need to build trust (Mei \& Dinwoodie, 2005). The attitudes of the users are important but there is not a need for suspect about electronic documents because they are conspicuously advantageous. Benefits such as elimination of archive, saving process time, reduction of the cost and prevention of fraud are conspicuous. Negative attitude of the users against electronic documents resulted from lack of system interoperability and resistance to change (Civelek, Uca, \& Çemberci, 2015). Main parties in a foreign trade transaction are exporter, importer, logistics Company, insurance company, customs administration and bank. Electronic documents began to replace the paper documents that are being currently used in foreign trade but full integration all of these parties are needed in order to use electronic 
documents in foreign trade (Civelek \& Sözer, 2003). The benefits of electronic documents are as follows; cost reduction, less process time, increase of interoperability, elimination of the human labor force, decrease in the archive costs, taking under recording of the economic activities, prevention of fraud, reduction of the number of documents, elimination of the complex payment methods, making commercial information as quickly accessible, increase in trade volume, predictable costs and elimination of language differences. The most important of these are the elimination of complexity payment methods and the reduction of the number of documents. For reduction of the number of documents there is a need for simplification. The most important benefits of simplification are transaction time and cost decrease (Civelek \& Seçkin, 2017).

\section{Scale Development Process}

Scale development process consists of two phases. In the first phase, the items were generated by means of qualitative interview study. This qualitative interview study was conducted in order to determine the dimensions. In this study, it was found that the paperless trade performance has primary and secondary dimensions. This scale measures the paperless trade performance under the primary dimensions (payment, customs, insurance, transport, archiving) and the secondary dimensions (speed, errors, costs, security, predictability, tracking \& tracing, reporting) in a nested manner. In the second phase, confirmatory factor analysis was conducted by implementing multitrait-multimethod model.

\section{a. Qualitative Interview Study \& Proposed Scale}

In the qualitative interview study, face-to-face meetings were held with 16 senior and midlevel professional managers in last quarter of $2016^{8}$. These interviews were semi-structured. Managers in the sample were chosen from the foreign trade companies. Interview subjects consist of 4 females (25\%) and 12 males (75\%), 10 senior (62,5\%) and 6 mid-level (37,5\%) professional managers. At the end of the first phase, 12 dimensions were appeared as 5 of them were primary, 7 of them were secondary. Each primary dimension has 5 secondary dimensions. These primary and secondary dimensions need to be handled as nested approach. Thus 35 items measurement scale was emerged. In Table 1., proposed scale items are shown.

\footnotetext{
${ }^{8}$ The first phase of this study was presented as an oral presentation at the conference (2nd international scientific conference the threats and challenges of security in the modern world in the area of political and financial security) held in Poland on 20th and 21st September 2017.
} 
Table 1. Proposed Scale Items

Payment

1. After starting to use electronic documents, our payments processes have been accelerated.

2. After starting to use electronic documents, errors in our payments processes have been decreased.

3. After starting to use electronic documents, costs of our payments processes have been decreased.

4. After starting to use electronic documents, security problems arising in our payments processes have been decreased.

5. After starting to use electronic documents, problems in our payments processes have become to be foreseeable.

6. After starting to use electronic documents, payments have become easier to trace.

7. After starting to use electronic documents, the processes of payment and reporting have become easier.

\section{Customs}

1. After starting to use electronic documents, customs clearance transactions have been completed faster than before.

2. After starting to use electronic documents, errors in customs clearance transactions have been decreased.

3. After starting to use electronic documents, cost in customs clearance transactions have been decreased.

4. After starting to use electronic documents, security problems arising from customs clearance transactions have been decreased.

5. After starting to use electronic documents, problems in customs clearance transactions have become to be foreseeable.

6. After starting to use electronic documents, customs clearance transactions have become easier to trace.

7. After starting to use electronic documents, reporting of 


\begin{tabular}{|l|}
\hline \multicolumn{1}{|c|}{ Insurance } \\
\hline $\begin{array}{l}\text { 1. After starting to use electronic documents, insurance } \\
\text { transactions have been completed faster than before. }\end{array}$ \\
\hline $\begin{array}{l}\text { 2. After starting to use electronic documents, errors in insurance } \\
\text { transactions have been decreased. }\end{array}$ \\
\hline $\begin{array}{l}\text { 3. After starting to use electronic documents, costs in insurance } \\
\text { transactions have been decreased. }\end{array}$ \\
\hline $\begin{array}{l}\text { 4. After starting to use electronic documents, security problems } \\
\text { arising from insurance transactions have been decreased. }\end{array}$ \\
\hline $\begin{array}{l}\text { 5. After starting to use electronic documents, problems in } \\
\text { insurance transactions have become to be foreseeable. }\end{array}$ \\
\hline $\begin{array}{l}\text { 6. After starting to use electronic documents, insurance } \\
\text { transactions have become easier to trace. }\end{array}$ \\
\hline $\begin{array}{l}\text { 7. After starting to use electronic documents, reporting of } \\
\text { insurance transactions have become easier. }\end{array}$ \\
\hline
\end{tabular}

\section{Transport}

1. After starting to use electronic documents, transport operations have been completed faster than before.

2. After starting to use electronic documents, errors in transport operations have been decreased.

3. After starting to use electronic documents, costs in transport operations have been decreased.

4. After starting to use electronic documents, security problems arising from transport operations have been decreased.

5. After starting to use electronic documents, problems in transport operations have become to be foreseeable.

6. After starting to use electronic documents, transport operations have become easier to trace.

7. After starting to use electronic documents, reporting of transport operations have become easier. 


\section{Archiving}

1. After starting to use electronic documents, archiving operations have been completed faster than before.

2. After starting to use electronic documents, errors in archiving operations have been decreased.

3. After starting to use electronic documents, costs in archiving operations have been decreased.

4. After starting to use electronic documents, security problems arising from archiving operations have been decreased.

5. After starting to use electronic documents, problems in archiving operations have become to be foreseeable.

6. After starting to use electronic documents, documents in archive have become easily accessible.

7. After starting to use electronic documents, it becomes easy to use documents in archive in reporting.

\section{b. Methodology for Testing Construct Validity}

In order to confirm construct validity of the measurement scale items that were found in first phase, confirmatory factor analysis was conducted in the second phase. It is decided that the most appropriate method for nested dimension was multitrait-multimethod model. By means of this model, convergent validity, discriminant validity and method effects were detected in order to confirm construct validity according Campbell and Fiske (Campbell \& Fiske, 1959). In testing for evidence of construct validity within the framework of the general CFA model, the guidelines put forward by Widaman was followed (Widaman, 1985). In this method, there are four models. The first model is the hypothesized model (Model 1) and the others are alternative models (Model 2, Model 3 and Model 4). Model 1 is general CFA model which the base model for the comparison with the alternative models. Model 1 is shown in the Figure 2. This model comprises freely correlated traits and freely correlated methods. Traits are in the left side of the model and method are in the right side of the model. The traits are correlated among themselves and methods are correlated among themselves. Correlation between traits and methods are assumed to be zero. In generally in order to solve inadmissible model problem which is stems from negative variance associated error terms, post hoc model should be used. In Figure 3., post hoc model is shown. As shown in Figure 2, variances of the latent variables of the traits and methods dimensions are fixed to 1 . Looking at the parameter summaries in Table 2, it is seen that the variance of 12 variables were kept 
fixed. It is also seen that the variance of 35 error terms obtained as a result of estimation were free. 70 regression coefficients were calculated freely for factor loadings and 35 regression coefficients for error terms were fixed. Therefore, there are a total of 105 regression weights. In this case, when the fixed regression weights and latent variable variances are evaluated together, it is seen that a total of 47 parameters were kept fixed. There are totally 183 parameters in the whole model.

Table 2. AMOS Parameter Summary for Initially Hypothesized Model

\begin{tabular}{|l|c|c|c|c|c|c|}
\hline & Weights & Covariances & Variances & Means & Intercepts & Total \\
\hline Fixed & 35 & 0 & 12 & 0 & 0 & 47 \\
\hline Labeled & 0 & 0 & 0 & 0 & 0 & 0 \\
\hline Unlabeled & 70 & 31 & 35 & 0 & 0 & 136 \\
\hline Total & 105 & 31 & 47 & 0 & 0 & 183 \\
\hline
\end{tabular}

The matrix structure in the background of the hypothesized model is as shown in Figure 1. Due to the difficulty of displaying it, only a limited drawing including Payment, Customs and Insurance methods was made. In Figure 1., Heteromethod Blocks, Monomethod Blocks, Heterotrait-Monomethod Triangles and Heterotrait-Heteromethod Triangles are shown. Model 2 which is shown in Figure 4. is one of the alternative models. Trait are not included in Model 2 and methods freely correlated among themselves. Another alternative model which is shown in Figure 5. is Model 3. In this models traits are perfectly correlated (covariances are equals to 1 ) and methods freely correlated among themselves. The last alternative model which is shown in Figure 6. Is Model 4. In this model traits are freely correlated and methods are uncorrelated. For testing the evidence of construct validity (convergent and discriminant validity), matrix level analyses and parameter level analyses were conducted. In matrix level analyses, comparison of the fit indices of all MTMM models was made. Fit indices values are shows in Table 3. Parameter differences of the each alternative models from Model 1 are summarized in Table 4. 


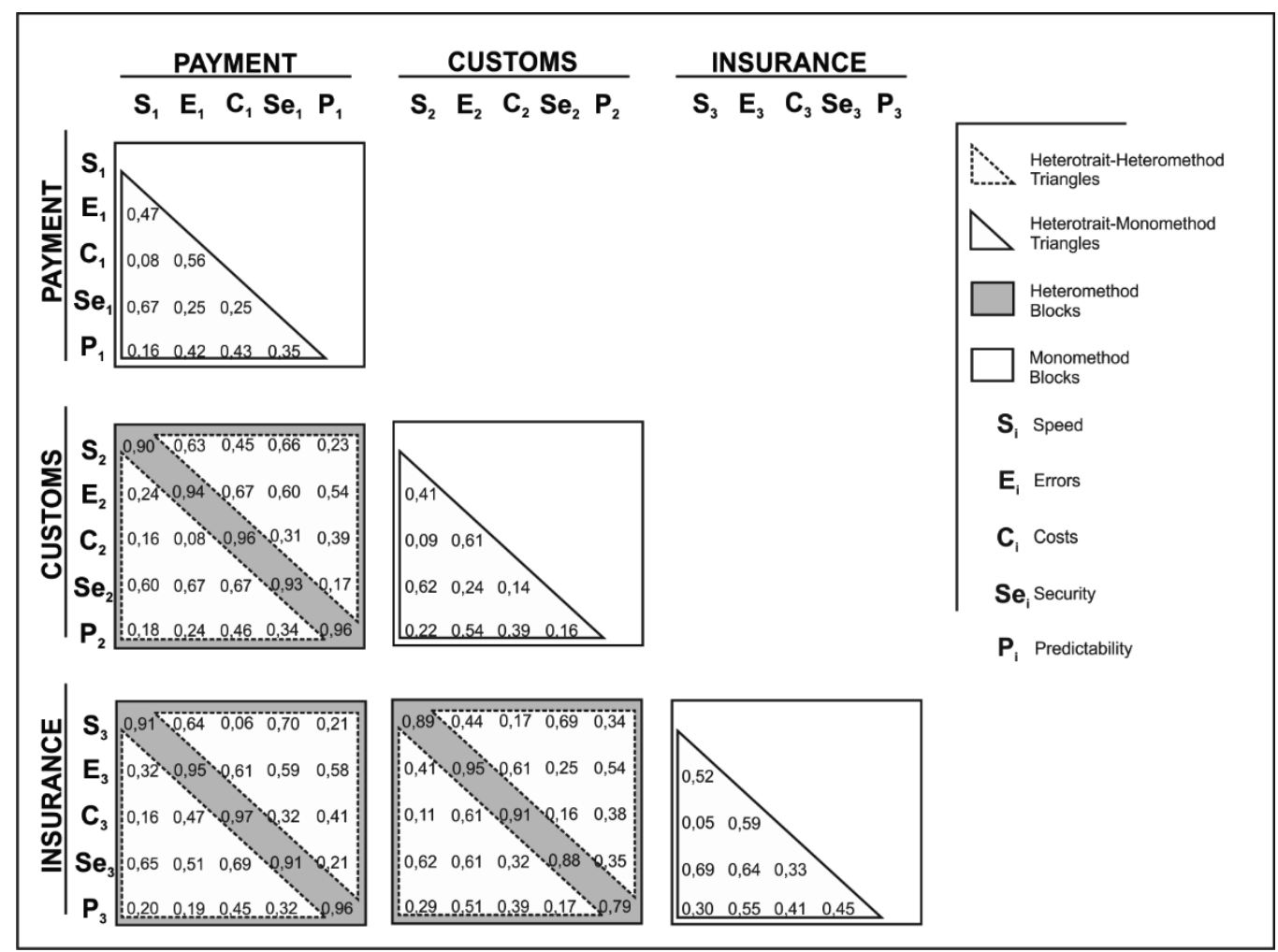

Figure 1. MTMM Matrix 


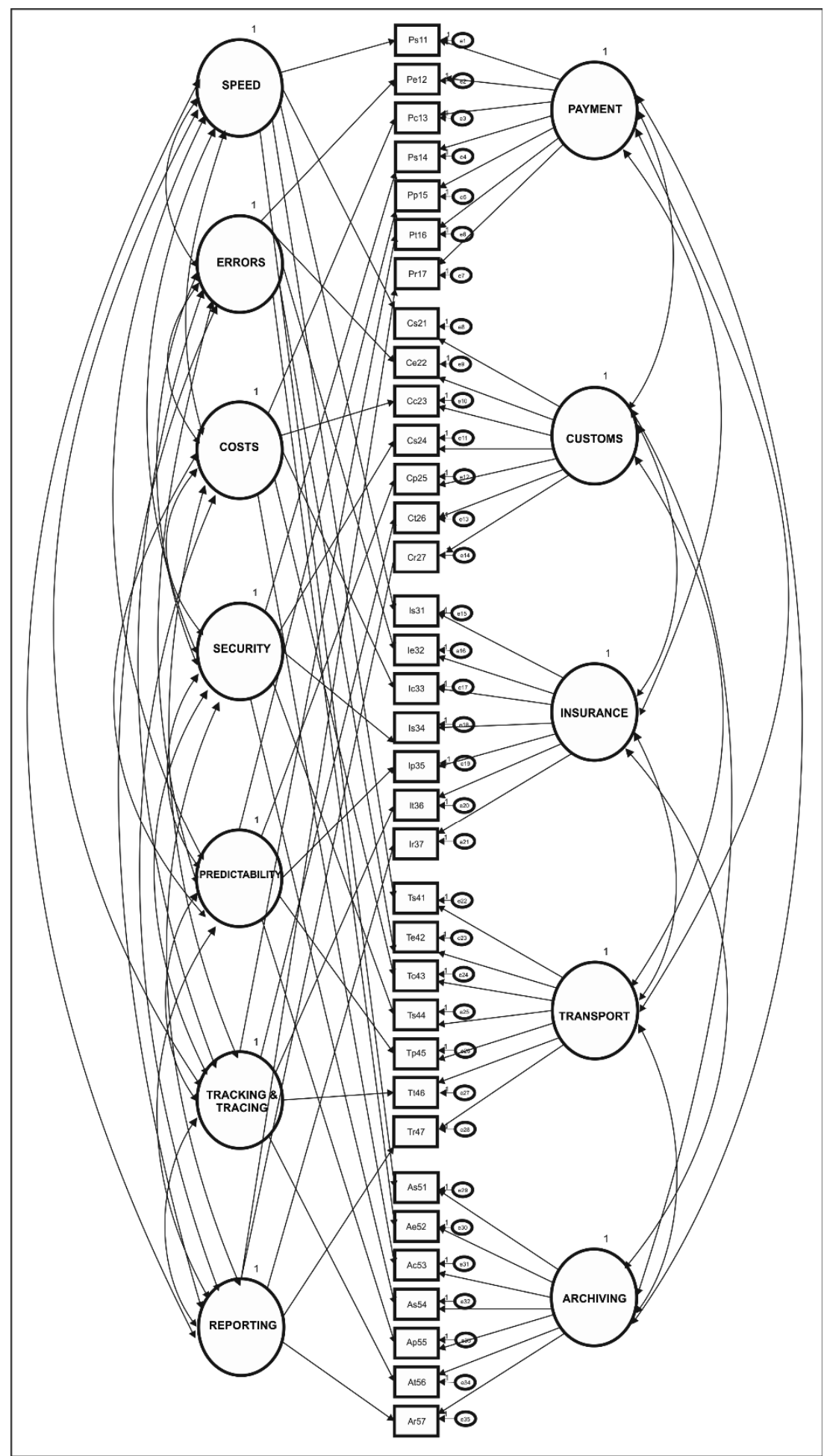

Figure 2. Model 1 (freely correlated traits; freely correlated methods) 


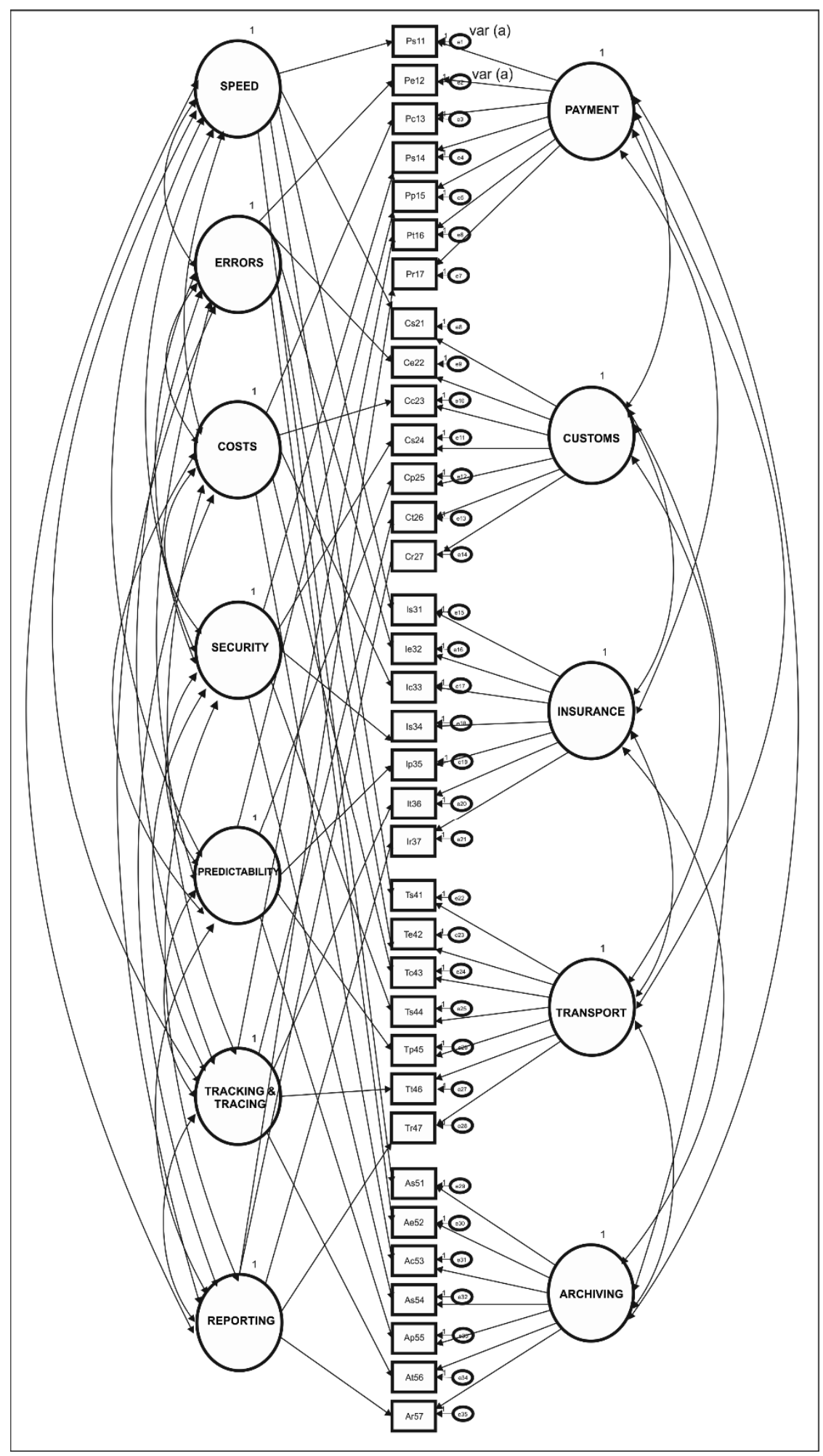

Figure 3. Post Hoc Model 


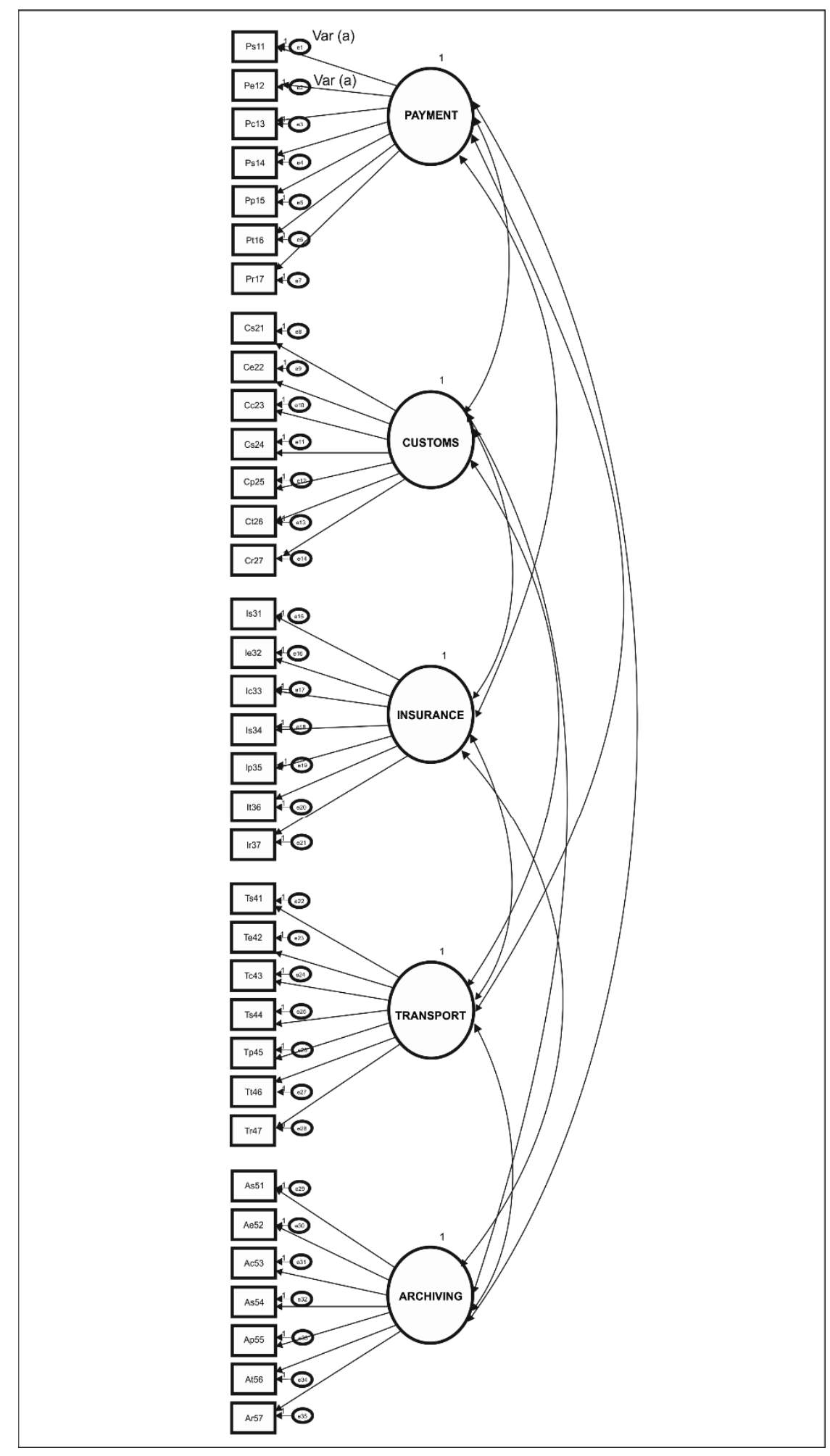

Figure 4. Model 2 (no traits; freely correlated methods) 


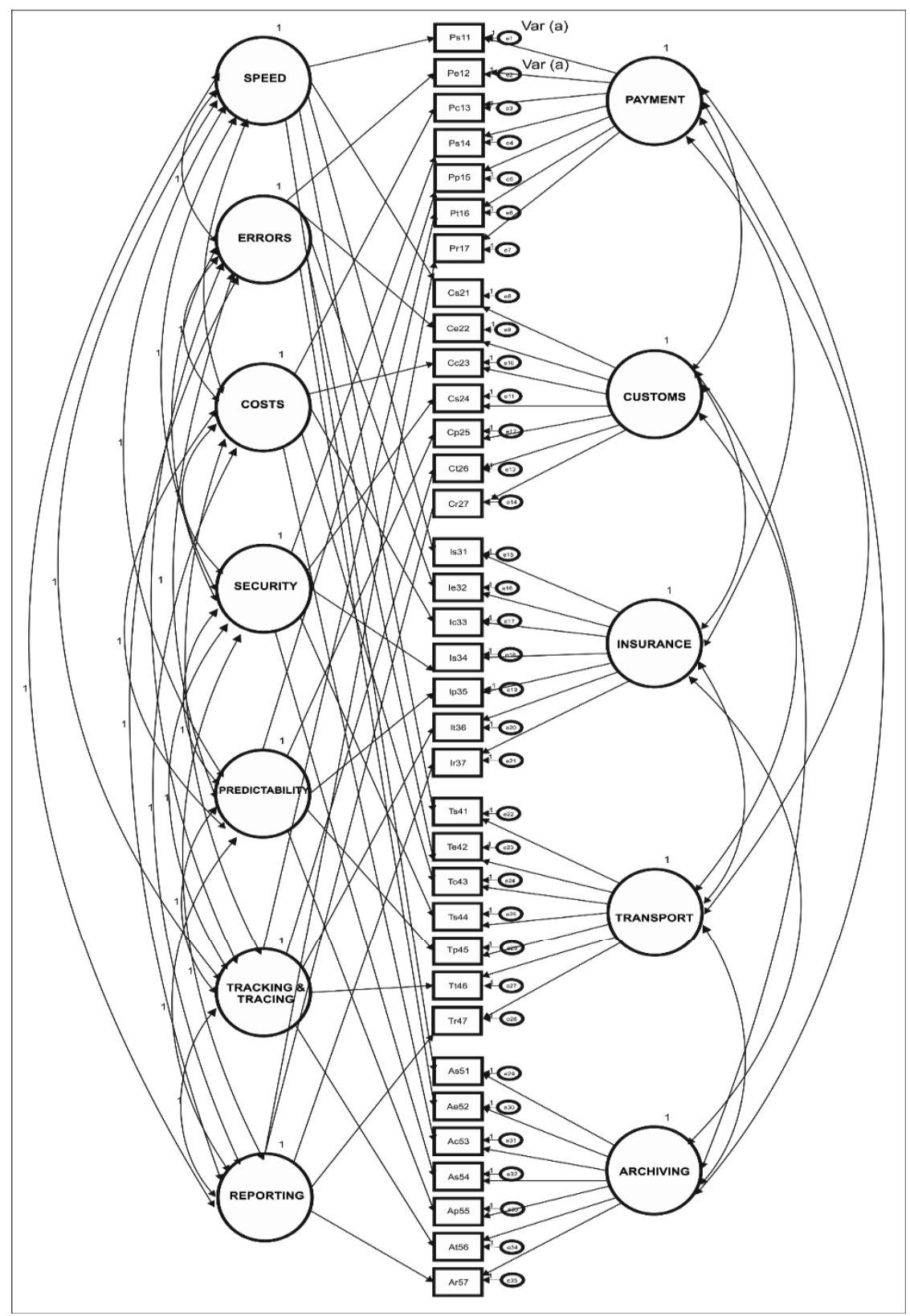

Figure 5. Model 3 (perfectly correlated traits; freely correlated methods) 


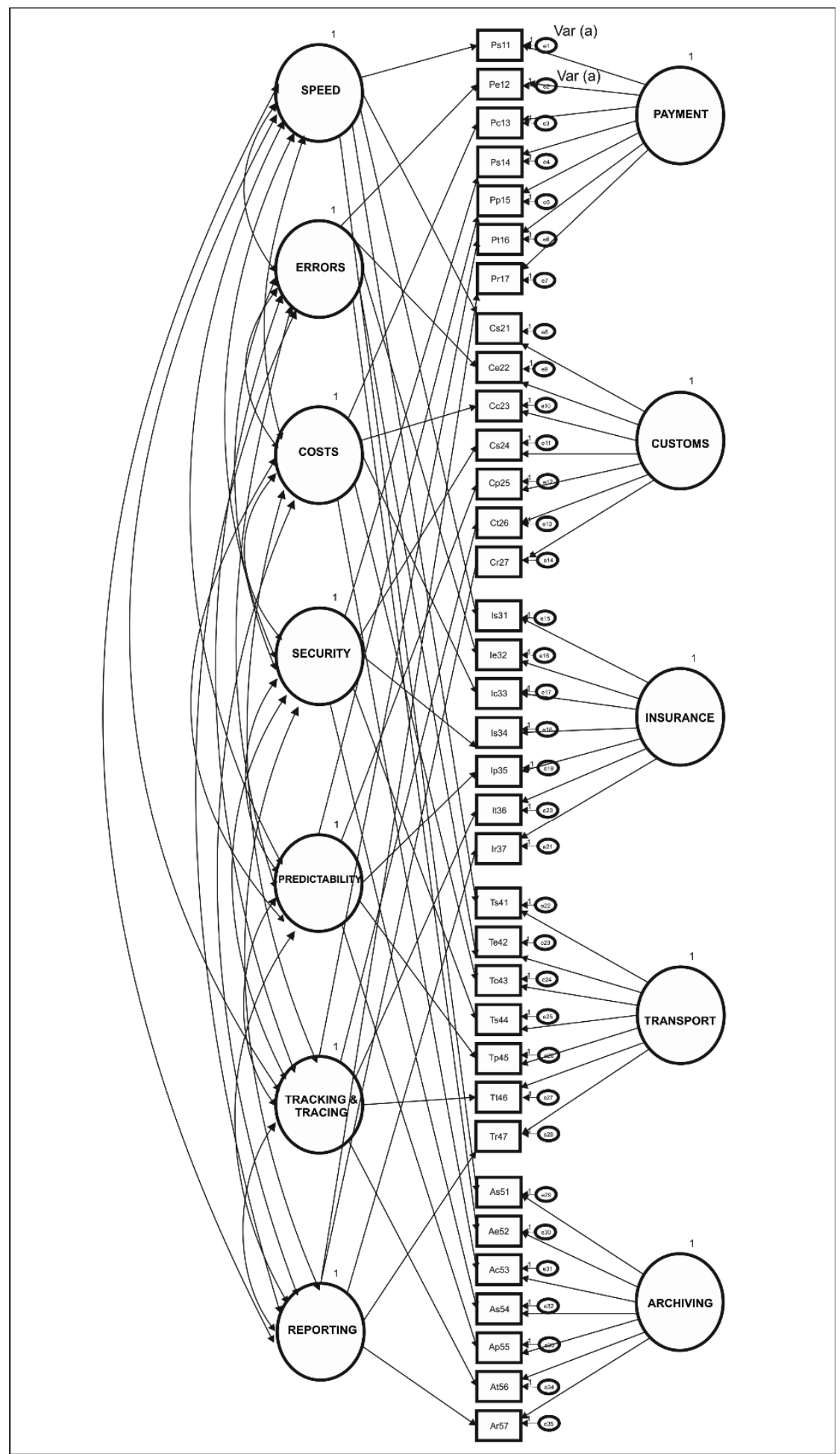

Figure 6. Model 4 (freely correlated traits; uncorrelated methods) 
Table 3. Parameter Summary

\begin{tabular}{|l|c|c|c|c|c|c|}
\hline \multicolumn{1}{|c|}{ Models } & \multicolumn{5}{|c|}{ Fit Indices } \\
\cline { 2 - 7 } & $\mathrm{x}^{2}$ & $\mathrm{df}$ & CFI & RMSEA & $90 \%$ C.I. & PCLOSE \\
\hline $\begin{array}{l}\text { 1. Freely correlated } \\
\text { traits; freely } \\
\text { correlated methods }\end{array}$ & 86.622 & 78 & .897 & .015 & $.000, .048$ & .897 \\
\hline $\begin{array}{l}\text { 2. No traits; freely } \\
\text { correlated methods }\end{array}$ & 459.128 & 98 & .693 & .204 & $.122, .157$ & .000 \\
\hline $\begin{array}{l}\text { 3. Perfectly correlated } \\
\text { traits; freely } \\
\text { correlated methods }\end{array}$ & 317.124 & 85 & .795 & .086 & $.081, .110$ & .000 \\
\hline $\begin{array}{l}\text { 4. Freely correlated } \\
\text { traits; uncorrelated } \\
\text { methods }\end{array}$ & 123.392 & 81 & .964 & .058 & $.037, .065$ & .000 \\
\hline
\end{tabular}

Table 4. Parameter Differences

\begin{tabular}{|c|c|c|c|c|}
\hline \multirow{2}{*}{ Model comparisons } & \multicolumn{2}{|c|}{ Differences in } & \\
\cline { 2 - 5 } & $\mathrm{x}^{2}$ & $\mathrm{df}$ & $\mathrm{CFI}$ & P value \\
\hline Test of convergent validity & & & & \\
\hline Model 1 versus Model 2 (traits) & 372.506 & 20 & .204 & 0.00 \\
\hline Test of discriminant validity & & & & \\
\hline Model 1 versus Model 3 (traits) & 230.502 & 7 & .102 & 0.00 \\
\hline Model 1 versus Model 4 (methods) & 74.230 & 3 & .067 & 0.00 \\
\hline
\end{tabular}

Significant differences in $X^{2}$ values between Model 1 and Model 2 are basis for the judgement of convergent validity. As shown in Table 4., $\Delta X^{2}(372.506, p<0.01)$ and $\Delta$ CFI $(0.204, p<0.01)$ were significant. Similarly, significant differences in $X^{2}$ values between Model 1 versus Model 3 and Model 1 versus Model 4 are basis for the judgement of discriminant validity. As shown in Table 4., for Model 1 versus Model $3 \Delta \mathrm{X}^{2}(230.502, \mathrm{p}<0.01)$ and $\Delta \mathrm{CFI}(0.102, \mathrm{p}<0.01)$ and for Model 1 versus Model $4 \Delta \mathrm{X}^{2}(74.230, \mathrm{p}<0.01)$ and $\Delta \mathrm{CFI}(0.067, \mathrm{p}<0.01)$ were significant. 
Another testing of the evidence of construct validity (convergent and discriminant validity) is parameter level analyses. In parameter level analyses, convergent and discriminant validity were examined according to individual factor loading and factor correlations. In Table 5 standardized estimates for factor loadings are shown.

Table 5. Trait and Method Factor Loadings for Model 1

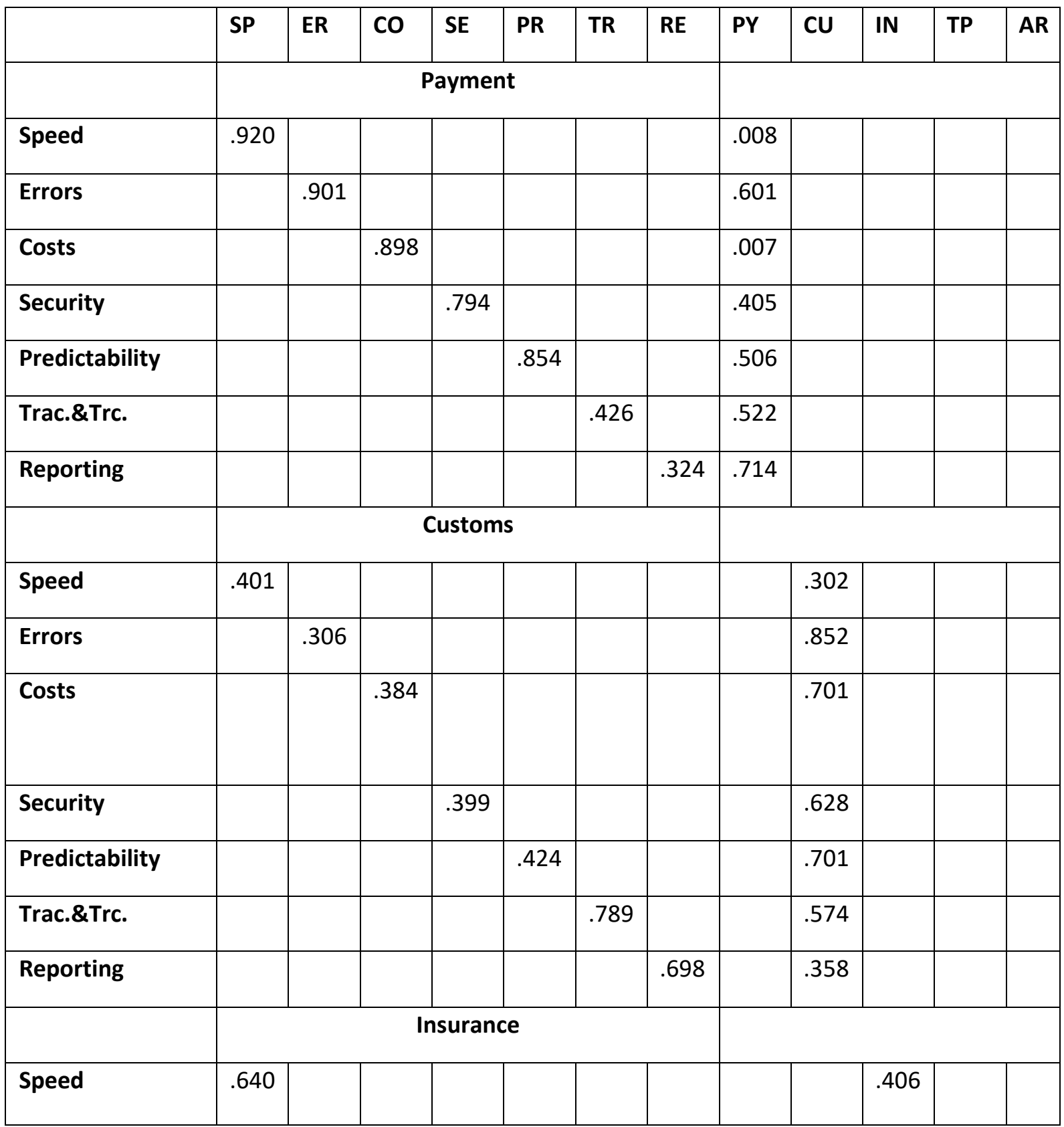




\begin{tabular}{|c|c|c|c|c|c|c|c|c|c|c|c|}
\hline Errors & & .501 & & & & & & & .720 & & \\
\hline Costs & & & .654 & & & & & & .506 & & \\
\hline Security & & & & .701 & & & & & .525 & & \\
\hline Predictability & & & & & .689 & & & & .603 & & \\
\hline Trac.\&Trc. & & & & & & & & & .745 & & \\
\hline \multirow[t]{3}{*}{ Reporting } & & & & & & .754 & & & .289 & & \\
\hline & & & & & & & .597 & & .374 & & \\
\hline & \multicolumn{7}{|c|}{ Transport } & & & & \\
\hline Speed & .256 & & & & & & & & & .356 & \\
\hline Errors & & .406 & & & & & & & & .902 & \\
\hline Costs & & & .250 & & & & & & & .604 & \\
\hline Security & & & & .274 & & & & & & .712 & \\
\hline Predictability & & & & & .372 & & & & & .586 & \\
\hline Trac.\&Trc. & & & & & & .755 & & & & .457 & \\
\hline Reporting & & & & & & & .743 & & & .771 & \\
\hline Speed & .595 & & & & & & & & & & .411 \\
\hline Errors & & .489 & & & & & & & & & .398 \\
\hline Costs & & & .525 & & & & & & & & .549 \\
\hline Security & & & & .424 & & & & & & & .375 \\
\hline Predictability & & & & & .445 & & & & & & .601 \\
\hline Trac.\&Trc. & & & & & & .379 & & & & & .832 \\
\hline Reporting & & & & & & & .408 & & & & .566 \\
\hline
\end{tabular}

Note: Path coefficients are standardized 
Table 6. Trait and Method Correlations ( $r$ ) for Model 1

\begin{tabular}{|c|c|c|c|c|c|c|c|c|c|c|c|c|}
\hline \multicolumn{8}{|c|}{ Traits } & \multicolumn{5}{|c|}{ Methods } \\
\hline Measures & SP & ER & CO & SE & PR & TR & RE & PY & CU & IN & TP & AR \\
\hline Speed (SP) & 1 & & & & & & & & & & & \\
\hline Errors (ER) & .345 & 1 & & & & & & & & & & \\
\hline Cost (CO) & .302 & .789 & 1 & & & & & & & & & \\
\hline Security (SE) & .220 & .720 & .487 & 1 & & & & & & & & \\
\hline Predict. (PR) & .351 & .698 & .501 & .607 & 1 & & & & & & & \\
\hline Trac.\&Tra.(TR) & .455 & .521 & .201 & .421 & .584 & 1 & & & & & & \\
\hline Reporting (RE) & .248 & .836 & .478 & .225 & .160 & .370 & 1 & & & & & \\
\hline Payment (PY) & & & & & & & & 1 & & & & \\
\hline Customs (CU) & & & & & & & & .197 & 1 & & & \\
\hline Insurance (IN) & & & & & & & & .201 & .421 & 1 & & \\
\hline Transport (TP) & & & & & & & & .254 & .428 & .222 & 1 & \\
\hline Archiving (AR) & & & & & & & & .218 & .648 & .168 & .334 & 1 \\
\hline
\end{tabular}

\section{Conclusion}

To measure the performance of foreign trade companies to perform paperless trade operations is needed. Because of the paperless trade is a new concept in foreign trade, there is a need for a measurement scale. Two-phases analysis was conducted in this research. At the end of this analysis, a method for developing a scale was proposed. Findings show that a complex nested model is needed to verify the validity of the scale. This model comprises primary and secondary dimensions. Primary dimensions correspond to the methods which are payment, customs, insurance, transport, archiving; secondary dimensions correspond to traits which are speed, errors, costs, security, predictability, tracking \& tracing, reporting. The 
theoretical contribution of this research is the development of a method for a scale in paperless trade. This proposal aims to enlighten the future studies. After repeated analysis by researchers in future this measurement scale would be confirmed. The managerial contribution of this research is to provide an instrument for assessing the paperless trade performance of foreign trade companies.

\section{REFERENCES}

Anderson, J. and D. Gerbing (1988). Structural Equation Modelling in Practice: A Review and Recommended Two-Step Approach. Psychological Bulletin.

Avcılar, M. and i. Varinli (2013). Perakende Marka Değerinin Ölçümü ve Yapısal Eşitlik Modeli Uygulaması (1 b.). Ankara: Detay Yayıncılık.

Bagozzi, R. P. and Y. Yi (1990). Assessing Method Variance in Multitrait-Multimethod Matrices: The Case of Self-reported Affect and Perceptions at Work. Journal of Applied Psychology, 75(1), p. 547-560.

Baron, R. and D. Kenny (1986). The Moderator-Mediator Variable Distinction in Social Phychological Research: Conceptual, Strategic and Statistical Considerations. Journal of Personality and Social Phychology, 6(51), p. 1173-1182.

Bayram, N. (2013). Yapısal Eşitlik Modellemesine Giriş. Bursa: Ezgi Kitapevi.

Bentler, P. M. and C.-P. Chou (1987). Practical Issues in Structural Modeling. Sociological Methods Research, 16(1), p. 78-117.

Björk, B.-C. (2006). Electronic document management in temporary project organisations Construction industry experiences. Online Information Review, 30(6), p. 644-655.

Byrne, B. M. (2010). Structural Equation Modeling with AMOS. New York: Routledge Taylor \& Francis Group.

Campbell, D. and D. Fiske (1959). Covergent and Discriminant Validation by the MultitraitMultimethod Matrix. Psychological Bulletin, 56, p. 81-105.

Chen, J., D. Rungruengsamrit, T. Rajkumar, and D. Yen (2013). Success of Electronic Web Sites: A Comparative Study in Two Countries. Information \& Management, 50(6), p. 344-355.

Civelek, M. E. and E. G. Sözer (2003). Internet Ticareti: Yeni EkoSosyal Sistem ve Ticaret Noktaları. İstanbul: Beta Basım. 
Civelek, M. E., N. Uca ve M. Çemberci (2015). eUCP and Electronic Commerce Investments: eSignature and Paperless Foreign Trade. Eurasian Acadeny of Sciences Eurasian Business \& Economics Journal, 3(1), s. 60-70.

Civelek, M. ve N. Seçkin (2017). Paperless Trade: Evaluation of the Current Situation \& towards the Integrated Single Foreign Trade Document. Journal of Management Research, 9(2), s. 1-10.

Civelek, M., M. Çemberci, N. Uca, Ü. Çelebi ve A. Özalp (2017). Challenges of Paperless Trade: Redesign of the Foreign Trade Process and Bundling Functions of Traditional Documents. International Business Research, 10(2), s. 74-81.

Civelek, M., H. İnce ve T. Karabulut (2016). The Mediator Roles Of Attitude Toward The Web Site And User Satisfaction On The Effect Of System Quality On Net Benefit: A Structural Equation Model On Web Site Success. European Scientific Journal, p. 61-73.

Çelik, H. E. ve V. YıImaz (2013). Lısrel 9.1 ile Yapısal Eşitlik Modellemesi. Ankara: Anı Yayıncılık. Doğan, i. (2015). Farkli Veri Yapisi ve Örneklem Büyüklüklerinde Yapisal Eşitlik Modellerinin Geçerliği ve Güvenirliğinin Değerlendirilmesi. Eskişehir: Eskişehir Osmangazi Üniversitesi Doktora Tezi.

Dursun, Y. ve E. Kocagöz (2010). Yapısal Eşitlik Modellemesi ve Regresyon: Karşılaştırmalı Bir Analiz. Erciyes Üniversitesi i.i.B.F. Dergisi (35), s. 1-17.

Fornell, C. and D. Lacker (1981). Evaluating Structural Equation Models with Unobservable Variables and Measurement Error. Journal of Marketing Research, 18(1), p. 39-50.

Gerbing, D. and J. Anderson (1988). An Updated Paradigm for Scale Development Incorporating Unidimensionality and Its. Joournal of Marketing Research, 25(2), p. 186-192.

Gujarati, D. (1999). Essentials of Econometrics (2 b.). Singapore: McGRAW-HILL.

Han, S., B. Nguyen and T. Lee (2015). Consumer-based chain restaurant brand equity, brand reputation, and. International Journal of Hospitality Management, 50(1), p. 84-93.

Jayaram, J., V. Kannan and K. Tan (2004). Influence of initiators on supply chain value creation. International Journal of Production Research, 42(20), p. 4377-4399.

Jervis, M. and M. Masoodian (2014). How do people attempt to integrate the management of their paper and electronic documents? Aslib Journal of Information, 66(2), p. 134-155. 
Kim, H.-M. and H.-h. Lee (2016). Asset specificity and capability of e-Trade performance: evidence from Korea. Journal of Korea Trade, 20(1), p. 2-20.

Laryea, E. (2005). Facilitating Paperless International Trade: A Survey of Law and Policy in Asia. International Review Of Law Computers, 19(2), p. 121-142.

Leyer, M. and M. Hollman (2014). Introduction of electronic documents: how business process simulation can help. Business Process Management, 20(6), p. 950-970.

Mei, Z. and J. Dinwoodie (2005). Electronic shipping documentation in China's international supply chains. Supply Chain Management: An International Journal, 10(3), p. 198-205.

Meydan, C. H. and H. Şen (2011). Yapısal Eşitlik Modellemesi AMOS Uygulamaları. Ankara: Detay Yayıncılık.

Raykov, T. (1997). Estimation of composite reliability for congeneric measures. Applied Psychological Measurement, 21(2), p. 173-184.

Raykov, T. and G. Marcoulides (2006). A First Course in Structural Equation Modeling. Mahwah: Lawrence Erlbaum Associates.

Schermelleh-Engel, K., H. Moosbrugger and H. Müller (2003). Evaluating the Fit of Structural Equation Models: Tests of Significance and Descriptive Goodness-of-Fit Measures. Methods of Psychological Research Online, 8(2), p. 23-74.

Sipahi, B., E. Yurtkoru ve M. Çinko (2010). Sosyal bilimlerde SPSS'le Veri Analizi. İstanbul: Beta Basım A.Ş.

Tabachnick, B. and L. Fidell (2001). Using multivariate statistics. Boston: Ally and Bacon.

Taşkın, Ç. ve Ö. Akat (2010). Araştırma Yöntemlerinde Yapısal Eşitlik Modelleme. Bursa: Ekin Basım Yayın.

Widaman. (1985). Hierarchically Tested Covariance Structure Models for MultitraitMultimethod Data. Applied Psychological Measurement, 9, p. 1-26.

Wu, J.-H. W. and Y.-M. Wang (2006). Measuring KMS Success: A Respecification of the DeLone and McLean's Model. Information \& Management, 43, p. 728-739. 